\title{
POSTKEYNESOWSKIE TEORIE ENDOGENICZNEJ PODAŻY PIENIĄDZA
}

\section{WSTĘP}

Endogeniczność podaży pieniądza jest fundamentem programu badawczego powstałego w latach siedemdziesiątych XX w. postkeynesizmu. Zgodnie z tą ideą podaż pieniądza jest określana przez potrzeby kredytowe podmiotów gospodarczych. Zmiany ilości pieniądza w obiegu są odpowiedzią na wahania poziomu aktywności gospodarczej, co oznacza, że stanowią rezultat - a nie przyczynę - fluktuacji dochodu nominalnego. Pieniądz kredytowy jest kreowany ex nihilo, implikując odwróconą przyczynowość (kredyty kreują depozyty) oraz odrzucenie koncepcji mnożnika pieniężnego i teorii ilościowej.

Zdaniem postkeynesistów we współczesnych gospodarkach opartych na kredycie nie ma technicznych możliwości kierowania podażą środków finansowych. Endogeniczna kreacja pieniądza jest więc immanentną cechą dzisiejszych systemów bankowych. Ponadto współczesne banki centralne pełnia ustawową funkcje pożyczkodawcy ostatniej instancji. Sa więc prawnie zobowiązane do tego, by dostarczać gospodarce niezbędnych środków pieniężnych. Kluczowym zadaniem władz jest dostosowywanie się do popytu na rezerwy banków komercyjnych w taki sposób, by zapotrzebowanie zgłoszone im przez wiarygodne podmioty prywatne zostało $\mathrm{w}$ pełni zaspokojone. W tej sytuacji jedyną zmienna, którą władze monetarne mogą efektywnie kontrolować, jest stopa procentowa. Tym samym nabiera ona charakteru egzogenicznego.

Postkeynesiści sa jednomyślni co do endogenicznego charakteru pieniądza i odwróconej przyczynowości, ale nie wszyscy jednakowo postrzegają rolę i działania banku centralnego w kierunku zaspokajania popytu na rezerwy zgłaszanego przez banki komercyjne. W trakcie toczacych się przez wiele lat dyskusji zarysowały się cztery zasadnicze postkeynesowskie podejścia do tej kwestii: akomodacyjne, strukturalistyczne, z perspektywy teorii obiegu pieniężnego oraz z perspektywy preferencji płynności. Celem artykułu jest przybliżenie tych stanowisk jako, po pierwsze, diametralnie odmiennych od poglądów przedstawicieli głównego nurtu, po drugie, jako różniących się między sobą co do zadań i możliwości podmiotów tworzących system bankowy. Zgodnie z założonym celem w części drugiej zaprezentowano koncepcje egzogeniczności i endogeniczności podaży pieniądza. Część trzecią poświęcono opisowi wspomnianych czterech postkeynesowskich po- 
dejść do endogeniczności pieniądza. W części czwartej przedstawiono wyniki najważniejszych badań empirycznych poświęconych postkeynesowskim mechanizmom kreacji pieniądza.

\section{EGZOGENICZNOŚĆ I ENDOGENICZNOŚĆ PODAŻY PIENIĄDZA}

Ujęcie z perspektywy pieniądza egzogenicznego jest kojarzone przede wszystkim z monetaryzmem i nową klasyczną ekonomia. Zgodnie z tym rozumowaniem bank centralny ustala wielkość bazy monetarnej, a dalszy proces kreacji pieniądza odbywa się za sprawą mnożnika pieniężnego ${ }^{1}$ :

$$
M=h_{m} H \text {. }
$$

Przyczynowość przebiega od strony prawej do lewej. Zmienną niezależna jest rozmiar bazy monetarnej $H$, kontrolowanej przez bank centralny, a zmienną zależną ilość cyrkulującego pieniądza $M$. Mnożnik $h_{m}$ jest z założenia stały (lub co najmniej stabilny) w czasie, co umożliwia władzom monetarnym kontrolowanie całkowitej podaży pieniądza². Bank centralny, wykorzystując leżące w jego gestii narzędzia polityki pieniężnej, czyli przede wszystkim operacje otwartego rynku i stopę rezerw obowiązkowych, określa rozmiary akcji kredytowej banków komercyjnych. Władze monetarne mają też możliwość kontrolowania popytu zagregowanego. Przyjmuje się tu bowiem stabilną funkcję popytu na pieniądz, łączącą agregaty pieniężne $\mathrm{z}$ dochodem całkowitym. Podaż pieniądza jest więc doskonale sztywna, wyznaczana przez władze monetarne niezależnie od popytu. Każda zmiana popytu na pieniądz, spowodowana zmianą preferencji płynności lub dochodu, prowadzi do zmiany stopy procentowej, która nabiera tym samym charakteru endogenicznego.

Z powyższego rozumowania wynika, że aby banki mogły udzielać kredytów, muszą najpierw zgromadzić odpowiednie rezerwy pieniądza. Pełnią więc rolę jedynie pośredników transferujących środki od podmiotów oszczędzających do podmiotów zaciagających dług. Ponadto obowiązuje tu klasyczna dychotomia, zgodnie z którą w długim okresie wielkości realne są niezależne od sfery pieniężnej. Zwiększenie podaży pieniądza może wywrzeć efekty realne jedynie przejściowo, gdy będzie stanowiło zaskoczenie lub gdy gospodarka okaże się zdominowana przez różnego rodzaju niedoskonałości, np. sztywne ceny i płace, uniemożliwiające ciągłe i natychmiastowe oczyszczanie się rynku.

Heterodoksyjne ujęcie z perspektywy pieniądza endogenicznego, typowe dla postkeynesizmu, przyjmuje całkowicie odmienną perspektywę. Zrywa ono z klasyczną dychotomią implikująca, że pieniądz w gospodarce jest jedynie „zasłona”. Immanentną cechą współczesnych gospodarek jest niepewność, która sprawia, że pieniądz nabiera cech niedostrzeganych $\mathrm{w}$ paradygmacie neoklasycznym. Pozwala bowiem zabezpieczyć się przed realizacją zdarzeń, któ-

${ }^{1}$ M. Lavoie, Foundations of Post-Keynesian Economic Analysis, Aldershot 1992, s. 170-172.

2 J. Haghighat, Endogenous and exogenous money: an empirical investigation from Iran, „Journal of Accounting, Finance and Economics” 1(1), 2011, s. 62. 
rych rozkład prawdopodobieństwa nie jest znany. To sprawia, że pieniądz jest nieneutralny zarówno w krótkim, jak i długim okresie. Co więcej, postkeynesiści podkreślaja, że proces produkcji wymaga czasu i zwykle musi być finansowany, zanim pojawią się jakiekolwiek jego efekty, które można zaoferować na rynku. Środki potrzebne już na etapie planowania inwestor pozyskuje od banków komercyjnych (lub innych instytucji finansowych). To z kolei oznacza, że banki reaguja na zgłaszany przez przedsiębiorców i gospodarstwa domowe popyt na kredyt, a nie popyt na depozyty. Stąd wniosek, że „kredyty kreuja depozyty", nie odwrotnie, jak sugeruje założenie egzogeniczności. Ujęcie z perspektywy endogeniczności koncentruje się na procesie kreowania długu, który jest istotna częścia procesu produkcji w gospodarce kapitalistycznej. Neguje tym samym ortodoksyjna teorię ilościowa, która wychodzi od ustalonych rozmiarów zasobu pieniądza i skupia się na jego wykorzystaniu jako środka wymiany, pomijając fakt, że pieniądz bierze udział w określaniu wszystkich kluczowych zmiennych ekonomicznych ${ }^{3}$.

Z tego wynika, że banki nie muszą gromadzić depozytów, aby rozpocząć akcję kredytowa, gdyż to właśnie akt udzielania kredytu i przekazania go na rachunek dłużnika kreuje równocześnie depozyt o odpowiedniej wysokości. Banki są więc w stanie stworzyć nową siłę nabywczą (nowe depozyty) bez konieczności redukowania zasobu pieniądza zgromadzonego przez oszczędzają$\mathrm{cych}^{4}$. W modelu pieniądza endogenicznego kredyt nie jest traktowany jako transfer środków od podmiotu oszczędzającego do dłużnika, lecz jako pierwotna kreacja przez bank siły nabywczej przekazywanej kredytobiorcy.

Mamy tu więc do czynienia z odwróconą przyczynowościa, zgodnie z która banki najpierw udzielają kredytów, a dopiero później pozyskują odpowiednie rezerwy na pokrycie swych rosnących aktywów. Podaż pieniądza jest doskonale elastyczna i pokrywa się z krzywą popytu na pieniądz kredytowy. Banki komercyjne zaspokajają zapotrzebowanie na nowe środki po danej cenie, a bank centralny zwiększa bazę monetarna proporcjonalnie do wzrostu kreacji pieniądza. Rozumowanie to można wyrazić za pomoca „dzielnika kredytowego" (credit divisor), zastępującego ortodoksyjny mnożnik pieniężny ${ }^{5}$ :

$$
H=d_{c} C .
$$

Przyczynowość należy ponownie odczytywać od strony prawej do lewej. W tym przypadku jednak to popyt na kredyt $C$ jest czynnikiem egzogenicznym, natomiast rozmiar bazy monetarnej endogenicznym.

Przy założeniu, że jedynymi aktywami banków komercyjnych są udzielone przedsiębiorstwom kredyty, popyt na kredyt staje się tożsamy z zasobem pieniądza w gospodarce, $M=C$. Dzielnik kredytowy będzie wtedy równy odwrotności mnożnika pieniężnego:

$$
H=\left(1 / h_{m}\right) C
$$

${ }^{3}$ L.R. Wray, Money and Credit in Capitalist Economies. The Endogenous Money Approach, Aldershot 1990, s. 16 i 72.

${ }^{4}$ S. Keen, Debunking macroeconomics, „Economic Analysis and Policy” 41(3), 2011, s. 155 i n.

${ }^{5}$ M. Lavoie, op. cit., s. 174. 
W praktyce rozmiar kredytów przyznanych sektorowi prywatnemu nie jest identyczny z zasobem pieniądza. Faktyczna wartość dzielnika kredytowego zależy więc od tego, jaką część portfela aktywów bankowych stanowia kredyty. Nadal istnieje jednak skończona relacja między zasobem pieniądza, na który społeczeństwo zgłasza popyt, a rozmiarem bazy monetarnej przez to zdeterminowanym. W tej sytuacji można zatem mówić o „dzielniku pieniężnym" (money divisor):

$$
H=\left(1 / h_{m}\right) M=d_{m} M
$$

Sektor finansowy dostosowuje się do popytu na kredyt zgłaszanego przez prywatny sektor niebankowy. W miarę jak firmy podejmują nowe inwestycje, banki udostępniają im więcej pieniądza na ten cel. Można to ujaćc w ten sposób, że „popyt na kredyt kreuje swoją własna podaż”. Jeżeli podaż pieniądza jest zdeterminowana prywatnymi decyzjami, czy podpisać umowę dłużną w celu sfinansowania wydatków, to nie może być ona bezpośrednio kontrolowana przez bank centralny ${ }^{7}$.

\section{POSTKEYNESOWSKIE UJĘCIA ENDOGENICZNEJ KREACJI PIENIĄDZA}

Koncepcja endogeniczności podaży pieniądza jest podstawą i sednem programu badawczego postkeynesizmu. Niemniej jednak, zgadzając się co do odwróconej przyczynowości przebiegającej od kredytu do agregatów pieniężnych oraz co do możliwości kreacji pieniądza ex nihilo, postkeynesiści wypracowali różniące się od siebie w szczegółach interpretacje odnośnie do działań banku centralnego i banków komercyjnych. W rezultacie zarysowały się cztery postkeynesowskie stanowiska w tej kwestii: akomodacyjne (horyzontalne), strukturalistyczne, z perspektywy teorii obiegu pieniężnego oraz z perspektywy preferencji płynności.

\section{Horyzontalizm}

Podejście akomodacyjne, zwane też horyzontalnym, jest identyfikowane przede wszystkim z nazwiskiem Basila J. Moore'a ${ }^{8}$. Uznaje się tu, że bank

${ }^{6}$ S. Gedeon, The Post Keynesian theory of money: a summary and an Eastern European example, „Journal of Post Keynesian Economics” 8(2), 1985, s. 208.

${ }^{7}$ M. Lavoie, op. cit., s. 73-74 i 89.

${ }^{8}$ B.J. Moore, A Post Keynesian approach to monetary theory, „Challenge” 21(4), 1978; idem, The endogenous money stock, „Journal of Post Keynesian Economics” 2(1), 1979; idem, Unpacking the Post Keynesian black box: bank lending and money supply, „Journal of Post Keynesian Economics" 5(4), 1983; idem, Wages, bank lending, and the endogeneity of credit money, w: M. Jarsulic (ed.), Money and Macro Policy, Boston 1985; idem, Contemporaneous reserve accounting: can reserves be quantity constrained?, „Journal of Post Keynesian Economics” 7(1), 1985; idem, How credit drives the money supply: the significance of institutional developments, „Journal of Economics Issues" 20(2), 1986; idem, Horizontalists and Verticalists: The Macroeconomics of Credit 
centralny suwerennie określa wysokość stopy procentowej, po której udziela żądanych przez banki komercyjne płynnych rezerw. Egzogenicznie ustalona wysokość stopy procentowej jest jedynym ograniczeniem dla banków komercyjnych chcących pozyskać potrzebne fundusze. Władze nie wprowadzają żadnych dodatkowych warunków czy barier, w tym ilościowych. Skoro cały popyt sektora bankowego na płynne zasoby jest pasywnie zaspokajany po ustalonej cenie, to krzywa podaży rezerw staje się doskonale elastyczna (horyzontalna) przy docelowej stopie procentowej. Takie zachowanie banku centralnego wynika z pełnionej przez niego funkcji pożyczkodawcy ostatniej instancji, który ma obowiązek zagwarantować systemowi bankowemu wymagany poziom płynności. Równocześnie oznacza to jednak utratę przez władze kontroli nad rozmiarami podaży pieniądza.

O ilości pieniądza w obiegu decyduje wysokość popytu sektora prywatnego na płynne zasoby. Jeżeli podmioty gospodarcze (w ujęciu indywidualnym lub zagregowanym) zechcą zwiększyć swoje zasoby pieniężne w celu realizacji planów produkcyjnych i zatrudnieniowych, zawsze będą w stanie to zrobić po określonej cenie (i po spełnieniu bankowych wymogów co do zabezpieczenia kredytu). Jest ona ustalana przez banki komercyjne jako narzut na stope procentową określoną odgórnie przez władze monetarne. Funkcję podaży pieniądza należy więc uznać za horyzontalną w każdym momencie. Całkowita ilość pieniądza jest endogeniczna i zdeterminowana popytowo, zarówno w krótkim, jak i długim okresie. W rezultacie pieniądz kredytowy, kreowany w celu sfinansowania aktywności gospodarczej, ma charakter nieneutralny, bez względu na rozpatrywany horyzont.

Ani banki komercyjne, ani bank centralny nie sa w stanie kontrolować podaży pieniądza kredytowego. Rozmiary kredytu mogą być ograniczone z inicjatywy banków tylko wtedy, gdy podniosa one oferowane oprocentowanie i wymogi co do zabezpieczenia długu. Z kolei jedyne co mogą zrobić władze, to ustalić cenę i warunki, na jakich będą dostarczać płynnych rezerw na żądanie systemu bankowego. Gdy bank centralny podwyższy lub obniży swoja stopę procentowa, horyzontalna funkcja podaży przesunie się w górę lub w dół, zachowując przy tym cały czas swój kształt.

\section{Strukturalizm}

Przedstawiciele podejścia strukturalistycznego, m.in. Robert Pollin ${ }^{9}$, Thomas I. Palley ${ }^{10}$ oraz L. Randall Wray ${ }^{11}$, odrzucaja ideę pełnej akomodacji jako nierealistyczna. Uważają bowiem, że bank centralny może ograniczyć bankom komercyjnym dostęp do płynnych rezerw, wykorzystując w tym celu operacje

\footnotetext{
Money, Cambridge 1988; idem, The endogenous money supply, „Journal of Post Keynesian Economics" 10(3), 1988.

${ }^{9}$ R. Pollin, Two theories of money supply endogeneity: some empirical evidence, „Journal of Post Keynesian Economics" 13(3), 1991.

10 T.I. Palley, Competing views of the money supply process: theory and evidence, „Metroeconomica" 45(1), 1994; idem, Accommodationism versus structuralism: time for an accommodation, „Journal of Post Keynesian Economics” 18(4), 1996.

${ }^{11}$ L.R. Wray, op. cit.
} 
otwartego rynku, które są głównym sposobem zapewniania płynności systemowi bankowemu. Oczywiście banki komercyjne są w stanie zdobyć potrzebne im środki finansowe z innych źródeł (np. z kredytu dyskontowego), ale zwykle będzie się to odbywało po wyższej cenie. A zatem w krótkim okresie bank centralny nie traci całkowicie kontroli nad podażą pieniądza, co oznacza, że idea pasywnej akomodacji nie jest prawdziwa. Tym samym zagregowana krzywa podaży kredytu nie jest horyzontalna, lecz nachylona dodatnio. Stopy oprocentowania kredytów natomiast nie mają charakteru egzogenicznego, lecz zmieniają się w sposób endogeniczny.

W dłuższym okresie sytuacja wygląda jednak nieco inaczej. Banki komercyjne jako instytucje nastawione na maksymalizację zysków będą bowiem starały się unikać narzucanych im odgórnie ograniczeń. W tym celu zaczna wprowadzać różnego rodzaju innowacje w oferowanych instrumentach finansowych i usługach oraz sposobie zarządzania portfelem aktywów i pasywów. To umożliwi im wygenerowanie dodatkowych płynnych środków i osłabienie pozycji banku centralnego. Intensyfikacja zarządzania daną struktura posiadanych należności i zobowiązań w celu wygenerowania potrzebnych rezerw jest tożsama ze wzrostem prędkości obiegu pieniądza. W odróżnieniu od podejścia horyzontalnego wzrost akcji kredytowej nie wynika tu ze wzrostu dostępnych na każde żądanie rezerw banku centralnego, lecz z ewolucji praktyk rynkowych o charakterze endogenicznym.

Zgodnie ze swą nazwą podejście to akcentuje rolę, jaką struktura z jednej strony popytu na poszczególne aktywa finansowe, a z drugiej - ich podaży odgrywają w wyznaczaniu wysokości stóp procentowych oraz rozmiarów aktywów finansowych, w tym podaży pieniądza. Popyt na aktywa zależy od potrzeb, preferencji, oczekiwań, kosztów transakcyjnych i warunków otoczenia gospodarczego. Z kolei podaż aktywów finansowych reaguje endogenicznie na popyt, ale sposób tej reakcji zależy w dużej mierze od realizowanej polityki pieniężnej. Podkreśla się przy tym, że uwalnianie rezerw przez zarządzanie portfelem wcale nie musi doprowadzić do wygenerowania takiej ich podaży, by w pełni zaspokoić zgłaszany popyt na kredyt. W tej sytuacji system bankowy zacznie doświadczać problemów z płynnościa, prowadzących do zakłóceń na rynku kredytowym i kryzysu finansowego. Strukturaliści zarzucają zwolennikom horyzontalizmu, że zjawiska niestabilności finansowej i załamań kredytowych nie zostały przez nich przeanalizowane w sposób satysfakcjonujący.

\section{Teoria obiegu pieniężnego}

Podejście to, znane $\mathrm{z}$ prac przede wszystkim Marca Lavoie ${ }^{12}$ oraz Louisa-Phillipe’a Rochona ${ }^{13}$, mieści się w założeniach horyzontalizmu. Jest jednak charakterystyczne z tego względu, że tezy o istnieniu doskonale elastycznej krzywej podaży pieniądza zostały wpisane w makroekonomiczny model obiegu pieniężnego rozwijany przez szkołę francusko-włoska, w szczególności Bernar-

12 M. Lavoie, op. cit.

${ }^{13}$ L.-P. Rochon, Credit, Money and Production. An Alternative Post-Keynesian Approach, Cheltenham 1999. 
da Schmitta, Augusto Grazianiego i Alaina Pargueza. Sednem jest tu identyfikacja grup podmiotów w gospodarce - przedsiębiorstw, pracowników i banków komercyjnych - posiadających różne cele i ograniczenia, między którymi występują asymetryczne zależności. Na tle tych współzależności analizowany jest cały cykl życia pieniądza od momentu jego wykreowania ex nihilo w ramach systemu bankowego, przez cyrkulację wynikająca z dokonywania płatności między podmiotami, aż do momentu ostatecznej jego likwidacji w chwili spłaty długu.

Kluczowe są relacje między przedsiębiorstwami i bankami, gdyż to one determinują dostępną ilość środków pieniężnych na rynku. Pieniądz, który ma charakter kredytowy, jest bowiem kreowany i wprowadzany na rynek w wyniku negocjacji między bankami i przedsiębiorstwami, przez co staje się zmienną endogeniczna. Stopa procentowa natomiast ma charakter egzogeniczny. Nowo wykreowany pieniądz bankowy jest wykorzystywany przez producentów do zapoczątkowania procesu produkcji, przede wszystkim zatrudnienia i opłacenia siły roboczej. Gdy przedsiębiorcy sprzedadzą swoje dobra pracownikom otrzymujacym wynagrodzenia, kredyty mogą zostać spłacone, co oznacza likwidację pieniądza. Ostateczne uregulowanie całego długu zamyka cykl obiegowy pieniądza.

Podaż pieniądza bankowego jest więc całkowicie zdeterminowana popytem na pieniądz zgłaszanym przez przedsiębiorców. Sektor bankowy jako całość, jak również pojedynczy bank, mają nieograniczoną możliwość kreacji kredytu, choć nie oznacza to przyznawania środków każdemu podmiotowi. Przedsiębiorstwa muszą bowiem spełnić ustalone kryteria wiarygodności, takie jak choćby odpowiednie zabezpieczenie długu. Banki nie sa więc pasywne w dostosowywaniu się do popytu na kredyt i mogą odmówić jego udzielenia tym, którzy nie spełniają narzuconych standardów. Odzwierciedleniem podziału siły nabywczej między różne podmioty jest system cen relatywnych. W konsekwencji pieniądz nigdy nie jest neutralny.

\section{Ujęcie z perspektywy preferencji płynności}

Podejście to, reprezentowane przez Charlesa Goodharta ${ }^{14}$ i Petera Howellsa ${ }^{15}$, w pełni akceptuje odwrócona przyczynowość, ale kwestionuje tezę postawiona przez horyzontalizm, zgodnie z która nie może wystapić nadwyżka pieniądza kredytowego, gdyż istnieje mechanizm zapewniający, że podaż nowych depozytów wykreowana przez strumień nowych kredytów jest zawsze dokładnie równa popytowi na te depozyty. Według horyzontalistów mechanizm ten opiera się na powszechnej akceptacji pieniądza jako środka płatniczego. W rezultacie „kredyty kreują depozyty”, które są utrzymywane przez podmioty, a niezależna funkcja popytu na pieniądz nie istnieje. A zatem na

${ }^{14}$ C. Goodhart, Has Moore become too horizontal?, „Journal of Post Keynesian Economics” 12(1), 1989.

${ }_{15}$ P.G.A. Howells, The demand for endogenous money, „Journal of Post Keynesian Economics” 18(1), 1995; idem, The demand for endogenous money: a rejoinder, ,Journal of Post Keynesian Economics" 19(3), 1997. 
gruncie empirycznym przyczynowość musi przebiegać jednokierunkowo od kredytów do depozytów, a następnie do podaży pieniądza.

Według zwolenników czwartego z postkeynesowskich podejść istnieje jednak popyt na pieniądz, niezależny od popytu na kredyty, co wynika z różnych preferencji płynności, jakie posiadaja podmioty gospodarcze. Kredyt jest zwykle zaciagany po to, by uregulować płatności za różnego rodzaju dobra i usługi. A zatem depozyty wykreowane przez kredyty niemal natychmiast zmieniaja swojego właściciela, który to może przekształcić otrzymany depozyt (przynajmniej częściowo) w gotówkę lub aktywa finansowe czy realne o wyższym zwrocie. Początkowo popyt na kredyt jest więc faktycznie równy popytowi na pieniądz, ale w dłuższej perspektywie równość ta jest nie do utrzymania. Co więcej, zmiany struktury portfeli zachodzace pod wpływem określonych preferencji płynności podmiotów wywierają wpływ na relatywne stopy procentowe, ceny, produkcję, a tym samym na dochód. Aby popyt na nowo wykreowane depozyty dokładnie odpowiadał popytowi netto na nowe kredyty, zmiany w relatywnych stopach procentowych musiałyby zachodzić nieustannie.

Stąd wniosek, że relacje kauzalne mogą mieć charakter dwukierunkowy. Z jednej strony może wystąić typowa dla horyzontalistów sekwencja, zgodnie z która przyczynowość przebiega od kredytu bankowego do depozytów i agregatów pieniężnych, z drugiej - może się okazać, że istnienie funkcji niezależnego popytu na pieniądz ograniczy zdolność kreowania depozytów przez kredyt. Implikuje to przyczynowość przebiegajaccą od podaży pieniądza do kredytu, która opiera się na koncepcji efektywnego rozmiaru utrzymywanych depozytów. Co więcej, mechanizm ten podważa stabilność mnożnika kredytowego. Może tu bowiem wystapić sprzężenie zwrotne między samym mnożnikiem a kredytem bankowym.

\section{BADANIA EMPIRYCZNE}

Jedne z najwcześniejszych badań empirycznych dotyczących endogeniczności pieniądza, prowadzone w ramach postkeynesizmu, zostały zaprezentowane przez Nicholasa Kaldora ${ }^{16}$ oraz Basila Moore'a ${ }^{17}$ i dotyczyły weryfikacji stanowiska horyzontalnego. Kaldor przeanalizował dane dla Wielkiej Brytanii za lata 1966-1979, z których wynikało, że podaż pieniądza jest zdeterminowana przez popyt na kredyty bankowe. Moore z kolei swoje liczne badania poświęcił analizie gospodarki amerykańskiej; w jednym z pierwszych opracowań $^{18}$, wykorzystując dane za lata 1951-1977, potwierdził swoje argumenty teoretyczne, wskazując przy tym na istotny związek między wzrostem wynagrodzeń a wzrostem popytu na kredyt zgłaszanym bankom komercyjnym, do którego bank centralny pasywnie się dostosowuje, dostarczając odpowiednich rezerw. Te zależności autor potwierdził w swych kolejnych badaniach.

${ }^{16}$ N. Kaldor, The Scourge of Monetarism, New York 1982.

17 B.J. Moore, The endogenous money stock...; idem, Unpacking...; idem, Horizontalists and Verticalists...; idem, The endogenous money supply.

${ }^{18}$ Idem, The endogenous money stock... 
Moore $^{19}$, analizując dane za lata 1964-1979, wskazał, że najważniejszym czynnikiem decydujaccym o zwiększeniu akcji kredytowej banków jest wzrost popytu przedsiębiorstw na środki finansujace kapitał obrotowy, przede wszystkim płace. Najsłynniejsza publikacja autora to oczywiście książka, w której obszerne rozważania teoretyczne zostały uzupełnione badaniami ekonometrycznymi ${ }^{20}$. W pełni potwierdziły one koncepcję pasywnych dostosowań banków komercyjnych do potrzeb sektora prywatnego.

Najbardziej znane wczesne badania dla wersji strukturalistycznej przeprowadził Pollin ${ }^{21}$, wykorzystując dane dla gospodarki amerykańskiej za lata 1953-1988. Na ich podstawie dowiódł, że perspektywa strukturalistyczna znacznie lepiej niż akomodacyjna opisuje zjawiska obserwowane na amerykańskim rynku finansowym. Opierając się na wynikach testów, autor sformułował cztery następujace wnioski: 1) rozmiar kredytów nie wzrasta proporcjonalnie do wysokości rezerw; 2) wzrost akcji kredytowej przekraczajacy dostępne rezerwy jest możliwy dzięki intensyfikacji praktyk zarządzania zobowiązaniami; 3) fundusze pochodzące z kredytu dyskontowego nie są dobrym substytutem środków dostarczanych w ramach operacji otwartego rynku, przy czym znaczenie tej substytucyjności maleje wraz z obserwowanym wzrostem roli zarządzania zobowiązaniami; 4) wysokość rynkowych stóp procentowych nie zależy wyłącznie od odgórnych interwencji, lecz jest zdeterminowana skomplikowanym zbiorem interakcji zachodzących między bankiem centralnym a rynkiem finansowym.

Badania empiryczne weryfikujące ujęcie z perspektywy obiegu pieniężnego są raczej rzadkościa. Jedną z niewielu kompleksowych analiz pokazujących całość cyrkulacji pieniądza zaprezentował Mario Seccareccia ${ }^{22}$. Przeprowadził on badania dla Kanady w latach 1969-2001 oraz dla Stanów Zjednoczonych w okresie 1973-2000. Wyniki pokazały, że inwestycje sektora prywatnego sa finansowane zarówno z kapitału własnego, jak i z kredytu bankowego. Wzrost zysków sektora prywatnego jest przeznaczany na spłatę długów bankowych zaciąniętych na zakup środków trwałych, co w efekcie redukuje popyt przedsiębiorstw na pieniądz kredytowy. Wzrost depozytów bankowych uniemożliwia zamknięcie cyklu obiegowego pieniądza, stąd wykazuje on dodatnia korelację ze wzrostem długu sektora przedsiębiorstw.

Ujęcie z perspektywy preferencji płynności zostało poddane weryfikacji przez Petera Howellsa i Khaleda Husseina ${ }^{23}$. Autorzy badali sytuację w krajach G7 w latach 1957-1993. Wyniki potwierdziły endogeniczność podaży pieniądza, wskazując równocześnie, że podmioty nie absorbują całego strumienia nowych depozytów wykreowanych przez kredyty. Wniosek ten stanowi potwierdzenie podejścia opartego na preferencji płynności. Sprzężenia zwrot-

${ }^{19}$ Idem, Unpacking...

${ }^{20}$ Idem, Horizontalists and Verticalists...

${ }^{21}$ R. Pollin, op. cit.

${ }^{22}$ M. Seccareccia, Pricing, investment and the financing of production within the framework of the monetary circuit: some empirical evidence, w: L.-P. Rochon, S. Rossi (eds.), Modern Theories of Money: The Nature and Role of Money in Capitalist Economies, Cheltenham 2003.

${ }^{23} \mathrm{P}$. Howells, K. Hussein, The endogeneity of money: evidence from the G7, „Scottish Journal of Political Economy" 45(3), 1998. 
nego między kredytami i depozytami dowiedli też Guglielmo M. Caporale i Peter Howells ${ }^{24}$, wykorzystując dane brytyjskie za lata 1970-1998.

Pozostałe analizy empiryczne dotyczące kwestii endogeniczności i weryfikacji poszczególnych ujęć postkeynesowskich są bardzo liczne. Warto tu wspomnieć m.in. o wynikach przedstawionych przez Thomasa I. Palleya ${ }^{25}$ dla danych amerykańskich za lata 1973-1990, które potwierdziły argumenty strukturalistów. Podobne rezultaty osiagną Deba R. Rath ${ }^{26}$ dla Indii za okres 1970-1997. Kevin Nell ${ }^{27}$ opisał badania dla Południowej Afryki obejmujące lata 1966-1997, dowodząc endogenicznej kreacji pieniądza zgodnie z postulatami zarówno horyzontalizmu, strukturalizmu, jak i ujęcia z perspektywy preferencji płynności. Alfonso P. Vera ${ }^{28}$ przeprowadził analizy dla Hiszpanii w okresie 1987-1998, potwierdzając ujęcie horyzontalistów i strukturalistów. Bala Shanmugam z zespołem ${ }^{29}$ przeanalizowali sytuację Malezji w latach 1985-2000 i wykazali istotność ujęcia z perspektywy preferencji płynności i akomodacyjnego. Badania dla Pakistanu obejmujace lata 1980-2003 pokazali Naved Ahmad i Fareed Ahmed $^{30}$. Wynikało z nich, że w krótkim okresie (do 18 miesięcy) można potwierdzić tezy strukturalizmu oraz preferencji płynności, a także częściowo horyzontalizmu. Natomiast w długim okresie pieniądz staje się egzogeniczny, a bank centralny odzyskuje wpływ na rozmiar podaży pieniądza. Endogeniczności pieniądza dla Rosji w latach 1995-2004 dowiodła Julia Vymyatnina ${ }^{31}$. Atilla Cifter i Alper Ozun ${ }^{32}$ analizowali dane dla Turcji za lata 1997-2006. Ich wyniki potwierdziły częściowo podejście horyzontalne, natomiast różniły się od strukturalistycznego i preferencji płynności. Działania mechanizmów postkeynesowskich dla krajów G7 w latach 1980-2003 (poza Francją i Japonia) dowiedli Yannis Panagopoulos i Aristotelis Spiliotis ${ }^{33}$. Podobne badania dla krajów G7 obejmujace okres 1973-2007 przedstawili Zatul E. Badarudin et al. ${ }^{34}$ Doszli oni do wniosku, że podaż pieniądza jest endogeniczna w długim okresie, ale w niektórych krajach banki centralne wciąż

${ }^{24}$ G.M. Caporale, P.G.A. Howells, Money, credit and spending: drawing causal inferences, „Scottish Journal of Political Economy” 48(5), 2001.

25 T.I. Palley, Competing views...

${ }^{26}$ D.P. Rath, Does money supply process in India follow a mixed portfolio: loan demand model?, „Economic and Political Weekly” 34(3-4), 1999.

${ }_{27}$ K.S. Nell, The endogenous/exogenous nature of South Africa's money supply under direct and indirect monetary control measures, „Journal of Post Keynesian Economics” 23(2), $2000-2001$.

28 A.P. Vera, The endogenous money hypothesis: some evidence from Spain 1987-1998, „Journal of Post Keynesian Economics" 23(3), 2001.

${ }_{29}$ B. Shanmugam, M. Nair, O.W. Li, The endogenous money hypothesis: empirical evidence from Malaysia (1985-2000), „Journal of Post Keynesian Economics” 25(4), 2003.

${ }^{30}$ N. Ahmad, F. Ahmed, The Long-run and short-run endogeneity of money supply in Pakistan: an empirical investigation, „State Bank of Pakistan - Research Bulletin” 2(1), 2006.

31 Y. Vymyatnina, How much control does Bank of Russia have over money supply?, „Research in International Business and Finance" 20(2), 2006.

32 A. Cifter, A. Ozun, The monetary transmission mechanism in the new economy: evidence from Turkey (1997-2006), „South East European Journal of Economics and Business” 2(1), 2007.

${ }^{33}$ Y. Panagopoulos, A. Spiliotis, Alternative money theories: a G7 testing, „Journal of Post Keynesian Economics" 30(4), 2008.

${ }^{34}$ Z.E. Badarudin, M. Ariff, A.M. Khalid, Post-Keynesian money endogeneity evidence in G-7 economies, „Journal of International Money and Finance” 33, 2013. 
mogą interweniować w krótkich okresach. Jafar Haghighat ${ }^{35}$ opisał badania dla Iranu dla lat 1968-2009. Testy okazały się zgodne z postkeynesowska teorią endogeniczności pieniądza. Sabri Nayan et al. ${ }^{36}$ zaprezentowali rezultaty osiagnięte dla 177 krajów w latach 1970-2011, które potwierdzaja postkeynesowską koncepcje endogeniczności pieniądza. Saud Almutair ${ }^{37}$ analizował sytuację Arabii Saudyjskiej w okresie 1997-2015. Autor potwierdził endogeniczność, ale wyłącznie w długim horyzoncie. Istotności wersji akomodacyjnej i od strony preferencji płynności dowiódł Emad O. Elhendawy ${ }^{38}$ dla danych egipskich obejmujacych lata 1990-2014. Oguzhan Cepni i Ibrahim E. Guney ${ }^{39}$ przedstawili rezultaty dla Turcji za lata 2006-2015. Według nich dane potwierdzają stanowisko horyzontalne, zarówno w krótkim, jak i długim okresie.

\section{ZAKOŃCZENIE}

Koncepcja endogeniczności pieniądza osadzona w heterodoksyjnej wizji funkcjonowania gospodarki jest jednym z wyróżników postkeynesizmu, stanowiącym o jego odmienności od głównego nurtu. Niemniej jednak postkeynesiści różnią się między sobą co do pewnych aspektów procesu endogenicznej kreacji pieniądza. Szczególnie ostre dyskusje toczyły się przez wiele lat między zwolennikami podejścia akomodacyjnego i strukturalistycznego. Cała debata, nierzadko bardzo emocjonalna, niewiele wniosła do ostatecznego rozstrzygnięcia wątpliwości teoretycznych. Mocno zaszkodziła natomiast pozycji postkeynesizmu, którego program badawczy uznano za mało spójny. Osłabiło to przekaz ekonomii postkeynesowskiej i podważyło jej znaczenie w poważnych dyskusjach naukowych.

Ta niekorzystna dla postkeynesistów sytuacja, potęgowana nieustannymi dyskusjami toczonymi między przedstawicielami rywalizujących ujęć na łamach piśmiennictwa naukowego, dała w końcu impuls do wypracowania uogólnionej teorii pieniądza endogenicznego, łączącej teoretyczne postulaty horyzontalizmu i strukturalizmu. Tego typu próby zaprezentowali m.in. Pierre Piégay $^{40}$, Giuseppe Fontana ${ }^{41}$ oraz Mark Setterfield ${ }^{42}$. Niestety wysiłki te po-

35 J. Haghighat, op. cit.

36 S. Nayan, M. Ahmad, N. Kadir, M.S. Abdullah, Post Keynesian endogeneity of money supply: panel evidence, MPRA Paper, 2013, nr 48716.

${ }^{37}$ S. Almutair, The endogenous money hypothesis: an empirical study of the Saudi Arabia, „International Journal of Social Science and Economics Invention” 1(3), 2015.

38 E.O. Elhendawy, Money supply - exogenous or endogenous? An empirical evidence from Egypt, „International Journal of Economics, Commerce and Management” 4(2), 2016.

39 O. Cepni, I.E. Guney, Endogeneity of money supply, „Journal of Finance and Banking Studies" 6(1), 2017.

${ }^{40}$ P. Piégay, Post Keynesian controversies on endogenous money: an alternative interpretation, w: L.-P. Rochon, S. Rossi (eds.), Modern Theories of Money. The Nature and Role of Money in Capitalist Economies, Cheltenham 2003.

${ }^{41}$ G. Fontana, Post Keynesian approaches to endogenous money: a time framework explanation, „Review of Political Economy” 15(3), 2003; idem, Rethinking endogenous money: a constructive interpretation of the debate between horizontalists and structuralists, „Metroeconomica” 55(4), 2004.

${ }_{42}$ M. Setterfield, An essay on horizontalism, structuralism and historical time, Trinity College Department of Economics Working Paper, 2014, nr 14-02. 
zostały w zasadzie niezauważone nie tylko przez ekonomistów o neoklasycznej proweniencji, lecz także i wielu postkeynesistów. W rezultacie teoria endogenicznej kreacji pieniądza, będąca filarem postkeynesowskiego programu badawczego wymierzonego w ekonomię głównego nurtu, wydaje się jego dużą słabością, m.in. z tego powodu krytycy postkeynesizmu uważaja, że próżno w nim upatrywać przekonującej alternatywy nie tylko dla opartej na ilościowej teorii pieniądza koncepcji egzogeniczności pieniądza, ale również dla koncepcji pieniądza endogenicznego rozwijanej obecnie przez główny nurt w ramach modelu nowej syntezy neoklasycznej ${ }^{43}$.

dr hab. Izabela Bludnik

Profesor Uniwersytetu Szczecińskiego

izabela.bludnik@wzieu.pl

\title{
POST-KEYNESIAN THEORIES OF ENDOGENOUS MONEY SUPPLY
}

\author{
Sum mary
}

One of the pillars of the research programme of heterodox Post-Keynesian economics is the endogenous creation of money supply, according to which the amount of money in circulation automatically accommodates to the needs reported by economic agents. Ensuring an adequate supply of funds is the role of commercial banks that create credit money ex nihilo, while monetary authorities are responsible for providing commercial banks with money reserves that guarantee the continuity of lending, and thus the process of the production and exchange in the economy. While the Post-Keynesians agree on the endogenous nature of money supply, not all of them perceive the role and operation of the central bank aimed at meeting the demand for reserves reported by commercial banks in the same way. As a result, four Post-Keynesian interpretations of this issue emerged: horizontalism, structuralism, an interpretation from the monetary circuit perspective and from the liquidity preference circuit. The purpose of this article is to present these approaches and to indicate the differences between them and the mainstream economics, as well as among themselves. The impact of such heterogeneity of views on the coherence of Post-Keynesianism and the ability of the school to create an alternative to neoclassical orthodoxy is also emphasised.

${ }^{43}$ Nowa synteza neoklasyczna jest oparta na założeniach neoklasycznych. W związku z tym, mimo że porzuciła ideę egzogenicznego pieniądza na rzecz jego endogenicznego charakteru, to pozostał on neutralnym środkiem wymiany, który w dłuższym horyzoncie nie ma żadnego wpływu na poziom produkcji i zatrudnienia. Co więcej, uznaje się tu, że endogeniczność pieniądza jest zjawiskiem przejściowym i odwracalnym. W sytuacji zmiany otoczenia gospodarczego banki centralne - jeżeli tylko byłoby to konieczne - mogłyby zrezygnować z ustalania stopy procentowej i powrócić do polityki kształtowania agregatów pieniężnych. Stopa procentowa z kolei jest tu cena równoważącą popyt na pieniądz z jego podażą. Pieniądz jest więc traktowany jak każde inne dobro - nadwyżka jego podaży doprowadzi do spadku ceny, a nadwyżkowy popyt wywoła wzrost ceny. 